\title{
Gouty tophus erodes nasal bone
}

\author{
Eva Rottmann ${ }^{1}\left[\right.$ David Bulbin ${ }^{1} \cdot$ Anthony Zaklama $^{2}$
}

Received: 18 June 2021 / Revised: 25 August 2021 / Accepted: 26 August 2021 / Published online: 2 October 2021

(c) The Author(s) 2021

\section{Presentation}

A 45-year-old Asian man with a 20-year history of gout is seen in clinic after lost to follow up for 10 years. He was previously treated with allopurinol but had been off therapy for many years. He describes several weeks of nasal bridge swelling with new episodes of snoring and apnea. On exam, he has a tender, erythematous mass over dorsum of nose with bulky tophi of multiple joints on hands, elbows, knees, and feet. Point-of-care ultrasound of his nasal bridge shows an area of inhomogeneous, hyperechoic aggregation with a hypoechoic rim consistent with gouty tophus [1]. Sinus CT without contrast shows a soft tissue partially calcified mass with bilateral nasal bone erosions. His uric acid was $12.6 \mathrm{mg} / \mathrm{dl}$. This case is a rare presentation of gouty tophi causing nasal bone erosions. The patient tested negative for hereditary enzyme deficiencies. He did test positive for HLA-B*5801 putting him at risk for allopurinol hypersensitivity syndrome. He was treated with febuxostat and eventually pegloticase infusions. With urate lowering therapy, his nasal mass size decreased, and apnea improved without need for surgical intervention (Fig. 1).

\section{Discussion}

Gout is increasingly recognized as a systemic urate deposition disease and can involve extra-articular deposition into soft tissue, tendons, and even cardiovascular tissue [2]. However, gouty tophus with nasal bone destruction is still extremely rare with only a few cases noted in literature [3]. Pathology can confirm monosodium urate crystals [4]. Ultrasound findings of gout such as a double-contour sign (a hyperechoic line of MSU crystals overlying cartilage) or "wet clumps of sugar" are well described in literature and may spare need for invasive tissue confirmation in the appropriate clinical setting [5]. Apneic symptoms can improve with medical treatment alone as nasal tophi decreases; however, some cases of refractory nasal obstruction and septal deviation have required surgical excision [6].

Eva Rottmann

Evaoconnel11314@gmail.com

David Bulbin

dhbulbin@geisinger.edu

Anthony Zaklama

azaklama@geisinger.edu

1 Department of Rheumatology, Geisinger Medical Center, M.C. 21-52, 100 N. Academy Avenue, Danville, PA 17822, USA

2 Department of Radiology, Geisinger Medical Center, M.C. 20-07, 100 N. Academy Avenue, Danville, PA 17822, USA 
Fig. 1 A Tender mass over nose. B Ultrasound of nasal bridge longitudinal view. C Transverse view-an area of inhomogeneous, hyperechoic aggregation with irregular margins, associated shadowing, and a surrounding hypoechoic rim compatible with a "wet clumps of sugar" appearance (white arrow). D Sinus CT without contrast shows a soft tissue mass with focal calcifications (circle) immediately adjacent to nasal bone erosion (arrow)
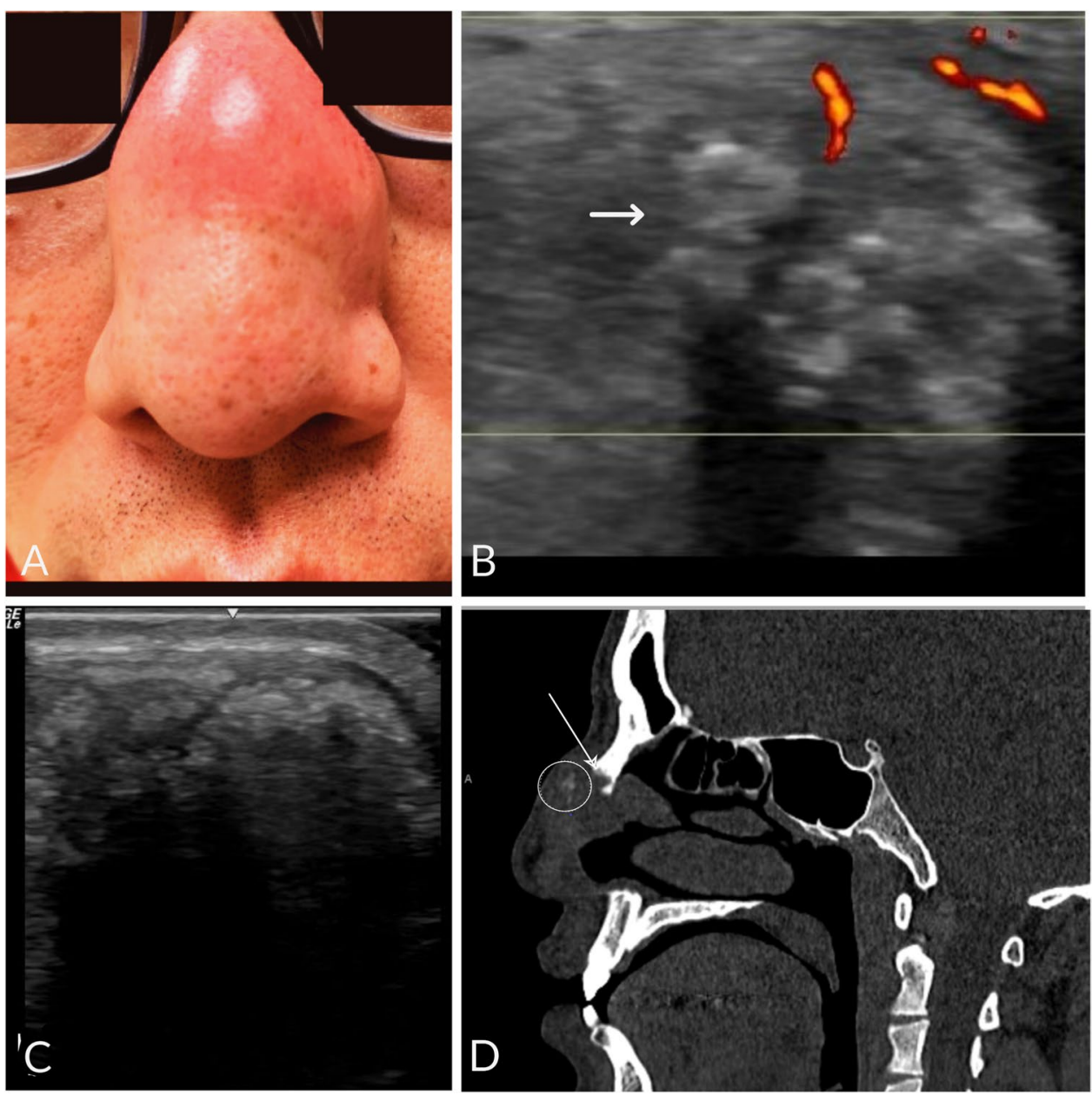

Funding Research is funded by Graduate Medical Education at Geisinger Medical Center.

\section{Declarations}

\section{Disclosures None.}

Informed consent Patient has consented to the publishing of data, photographs, and submission of the case report to the journal.

Open Access This article is licensed under a Creative Commons Attribution 4.0 International License, which permits use, sharing, adaptation, distribution and reproduction in any medium or format, as long as you give appropriate credit to the original author(s) and the source, provide a link to the Creative Commons licence, and indicate if changes were made. The images or other third party material in this article are included in the article's Creative Commons licence, unless indicated otherwise in a credit line to the material. If material is not included in the article's Creative Commons licence and your intended use is not permitted by statutory regulation or exceeds the permitted use, you will need to obtain permission directly from the copyright holder. To view a copy of this licence, visit http://creativecommons.org/licenses/by/4.0/.

\section{References}

1. Terslev L, Gutierrez M, Schmidt WA, Keen HI, Filippucci E, Kane D, Thiele R, Kaeley G, Balint P, Mandl P, Delle Sedie A, Hammer HB, Christensen R, Möller I, Pineda C, Kissin E, Bruyn GA, Iagnocco A, Naredo E, D'Agostino MA, OMERACT Ultrasound Working Group (2015) Ultrasound as an outcome measure in gout A validation process by the OMERACT Ultrasound Working Group. J Rheumatol 42(11):2177-81. https://doi.org/10.3899/ jrheum. 141294

2. Klauser AS, Halpern EJ, Strobl S et al (2019) Dual-energy computed tomography detection of cardiovascular monosodium urate deposits in patients with gout. JAMA Cardiol 4(10):1019-1028. https://doi.org/10.1001/jamacardio.2019.3201

3. Chen SL, Chen JR, Yang SW (2019) Painless gouty tophus in the nasal bridge: a case report and literature review. Medicine (Baltimore) 98(11):e14850. https://doi.org/10.1097/MD.0000000000 014850 
4. Wu JC, Chou PY, Chen CH (2016) Nasal gouty tophus: report a rare case presenting as a nasal hump with nasal obstruction. Biomed J 39(4):295-297. https://doi.org/10.1016/j.bj.2016.05.002

5. Thiele RG (2011) Role of ultrasound and other advanced imaging in the diagnosis and management of gout. Curr Rheumatol Rep 13(2):146-153. https://doi.org/10.1007/s11926-010-0156-4
6. Kwak PE, Gorman BK, Olson KL (2013) Nasal gout presenting as nasal obstruction. JAMA Otolaryngol Head Neck Surg 139(4):411-413. https://doi.org/10.1001/jamaoto.2013.220

Publisher's note Springer Nature remains neutral with regard to jurisdictional claims in published maps and institutional affiliations. 